\title{
HOXB2 is a Putative Tumour Promotor in Human Bladder Cancer
}

\author{
JIA LIU ${ }^{1,2 *}$, SHENG LI ${ }^{2 *}$, XIAOJING CHENG ${ }^{1,2}$, PENG DU $^{2}$, YONG YANG $^{2}$ and WEN G. JIANG ${ }^{1}$ \\ ${ }^{1}$ Cardiff China Medical Research Collaborative, Cardiff University School of Medicine, Cardiff, U.K.; \\ ${ }^{2}$ Key Laboratory of Carcinogenesis and Translational Research (Ministry of Education), Department of Urological Surgery, \\ Peking University Cancer Hospital and Institute, Beijing, P.R. China
}

\begin{abstract}
Background/Aim: The present study aimed to investigate the role of Homebox B2 (HOXB2) in bladder cancer (BC). Materials and Methods: The Cancer Genome Atlas (TCGA) dataset was used to analyse HOXB2 expression in $B C$. The influence of HOXB2 on the cellular functions of $B C$ cells was determined in both HOXB2 knockdown and HOXB2 overexpressed BC cell lines using in vitro assays. Results: HOXB2 mRNA was significantly upregulated in luminal infiltrated and luminal papillary subtypes of BC. Drug Metabolism Cytochrome P450 was significantly enriched in BCs expressing high levels of HOXB2. Knockdown of HOXB2 from EJ138 cells reduced growth, adhesion and invasion. In contrast, overexpression of HOXB2 in RT112 cells induced growth and adhesion of bladder cancer cells. Conclusion: Increased HOXB2 expression in papillary $B C$ can promote cell growth and adhesion of BC cells. Drug Metabolism Cytochrome P450 pathway was enriched in BCs overexpressing HOXB2.
\end{abstract}

Bladder cancer (BC) is one of the most common urogenital carcinomas, and its incidence is the second highest, immediately after prostate cancer. Most bladder cancers are histologically characterised as transitional cell carcinomas (TCC). Worldwide, the age-standardised incidence rate for

\footnotetext{
*These Authors contributed equally to this work.

Correspondence to: Professor Wen G. Jiang, Cardiff China Medical Research Collaborative, Cardiff University School of Medicine, Heath Park, Cardiff, U.K. Tel: +44 (0)29 20687065, e-mail: jiangw@cardiff.ac.uk; or Professor Yong Yang, Key Laboratory of Carcinogenesis and Translational Research (Ministry of Education), Department of Urological Surgery, Peking University Cancer Hospital and Institute, Beijing, PR China. Tel: +86 (0)10-88140650, email: yoya_urology@sina.com
}

Key Words: HOXB2, bladder cancer, papillary tumour, proliferation, cytochrome P450. males is 9.0 per 100,000 persons/year and 2.2 for females. In China, the incidence rate was 6.61 in 2012 (1). As a firstline therapy, surgery and chemotherapy are commonly used. Unfortunately, as this disease has a progression and recurrence rate of up to $50-70 \%$ (2), it is still difficult to predict the prognosis of BC. Aberrant chromosomal and genetic events have been reported in BC (3). However, understanding of the molecular mechanisms of $\mathrm{BC}$ remains poor and should be intensively explored.

Homeobox (HOX) genes commonly contain a characteristic 183-nucleotide sequence (homeobox). HOX genes encode transcription factors (4), which are involved in the regulation of differentiation, cell migration, cell growth, cell cycle, cellular identity and organogenesis (5). To date, 39 members have been identified in the HOX family and are divided into four groups, i.e. $\mathrm{A}, \mathrm{B}, \mathrm{C}$ and $\mathrm{D}$, according to their chromosomal location. Aberrant expression and function of HOX genes have been evident in a number of tumours, such as breast, leukemia, stomach, lung, liver and prostate cancer (6-11). Deregulated HOX has also been observed in BC (12-14).

Homeobox B2 (HOXB2) is located on chromosome 17 (15). HOXB2 encodes a transcription factor and acts as one of the key regulators of the morphogenesis and differentiation of cells (16). Expression of HOXB2 in the genital tubercle plays an essential role in embryonic development of external genitalia and urogenital tract (17). However, the expression and involvement of HOXB2 in BC have not yet been disclosed. The expression of HOXB2 and its prognostic significance in $\mathrm{BC}$ were investigated in the current study.

\section{Materials and Methods}

Materials and cell lines. EJ138 and RT112 human bladder cancer cell lines were obtained from the European Collection of Animal Cell Culture (ECACC, Salisbury, UK). The cells were cultured in DMEM-F12 medium supplemented with $10 \%$ fetal bovine serum (FBS) and antibiotics (penicillin and streptomycin). 
Table I. Primer sequences for polymerase chain reaction (PCR).

\begin{tabular}{lll}
\hline Primer & Forward & Reverse \\
\hline HOXB2 & 5' CCAAGAAACCCAGCCAATC 3' & 5' GTGTTGGTGTAAGCCGTGC 3' \\
GAPDH & 5' ATGATATCGCCGCGCTCGTC 3' & 5' GCTCGGTCAGGATCTTCA 3' \\
\hline
\end{tabular}

Construction of human HOXB2 expression vectors and transfection. Anti-human HOXB2 hammerhead ribozymes were designed by targeting appropriate cleavage sites following an analysis of the secondary structure of $H O X B 2 \mathrm{mRNA}$ using an online RNA folding tool (Zuker's RNA Mfold program, http://unafold .rna.albany.edu). The ribozymes were generated using touch-down PCR followed by cloning into the pEF6/V5-His-TOPO plasmid vector (Invitrogen, Ltd., Paisley, UK). Full-length human $H O X B 2$ coding sequence was amplified from a cDNA library of normal human bladder tissues, and was subsequently cloned into the same plasmid vector. GenElute Plasmid Mini-Prep Kit (Sigma-Aldrich, Inc., Poole, UK) was used to isolate the plasmids. Anti-HOXB2 ribozyme transgenes were used to create a knockdown model in EJ138 cells. After 3 weeks of selection using G418 (250 $\mu \mathrm{g} / \mathrm{ml})$, the selected cells were subsequently maintained in a medium containing $50 \mu \mathrm{g} / \mathrm{ml}$ of G418. EJ138 cells with HOXB2 knockdown were designated as EJ138-HOXB2-kd and used for the following experiments. HOXB2 expression and control vectors were transfected into RT112 cells. The cells were subject to the similar selection using G418 and stably strains that overexpressed HOXB2 were designated as RT112-HOXB2-exp and used for subsequent experiments.

RNA isolation, reverse transcription- $P C R(R T-P C R)$ and western blot analysis. TRI Reagent (Sigma-Aldrich, Inc.) was used for RNA isolation. The extracted RNA was then used as a template for the following RT using iScript cDNA Synthesis Kit (Bio-Rad Laboratories, Inc., Hercules, CA, USA). PCR amplification of the target genes was achieved by an initial denaturation at $95^{\circ} \mathrm{C}$ for $5 \mathrm{~min}$, followed by 36 cycles of $30 \mathrm{~s}$ at $95^{\circ} \mathrm{C}, 30 \mathrm{~s}$ at $55^{\circ} \mathrm{C}$ and $40 \mathrm{~s}$ at $72^{\circ} \mathrm{C}$, and a final extension at $72^{\circ} \mathrm{C}$ for $10 \mathrm{~min}$.

Cells were lysed in a lysis buffer containing $50 \mathrm{mM}$ Tris- $\mathrm{Cl}, \mathrm{pH}$ $7.5,1 \%$ Nonidet P-40, $0.5 \%$ sodium deoxycholate, $0.05 \%$ SDS, 1 mM EDTA, $150 \mathrm{mM} \mathrm{NaCl}$, aprotinin, leupeptin and sodium vanadate followed by quantification using a DCTM protein assay kit (Bio Rad Laboratories, Inc.). Protein extracts $(30 \mu \mathrm{g})$ were separated in $10 \%$ or $12 \%$ SDS-PAGE and then electrically blotted onto a $0.45 \mu \mathrm{m}$ polyvinylidenedifluoride membrane (EMD Millipore, Billerica, MA, USA). Membranes were then blocked for $1 \mathrm{~h}$ at room temperature with 5\% skimmed milk in PBST solution $(0.05 \%$ Tween-20 in PBS). Target proteins were probed with the corresponding primary antibodies (1:500) overnight at $4^{\circ} \mathrm{C}$, followed by incubation with the corresponding horseradish peroxidase (HRP)-conjugated secondary antibodies $(1: 2,000)$ for $1 \mathrm{~h}$ at room temperature. Anti-HOXB2 (catalog no SJ2465545; Thermo Fisher Scientific Inc., Waltham, MA, USA), and anti-GAPDH (cat. no. sc 32233; all Santa Cruz Biotechnology, Inc., Dallas, TX, USA), and anti-mouse IgG secondary antibodies (cat. no. A5278, Sigma Aldrich) were used for the western blots. The protein bands were visualized using the EZECL chemiluminescence kit (Biological Industries USA, Inc., Cromwell, CT, USA) and the Syngene G: BOX chemiluminescence imaging system (Syngene Europe, Cambridge, UK).
Cell proliferation assay. A standard procedure of crystal violet assay was used. EJ138 (2,000 cells/well) and RT112 (4,000 cells/well) cells were seeded on 96-well plates. The number of cells was determined at days 1,3 , and 5 by reading the absorbance after crystal violet staining. Briefly, the cells were fixed followed by staining with $0.1 \%$ crystal violet, which was then dissolved in $10 \%$ acetic acid. The absorbance was then quantified with a spectrophotometer (Elx800; Bio-Tek, Bedfordshire, UK) at $540 \mathrm{~nm}$.

Cell-matrix adhesion assay. A 96-well plate was coated with Matrigel $(5 \mu \mathrm{g} / 100 \mu \mathrm{l} / \mathrm{well})$. The wells were rehydrated for $30 \mathrm{~min}$ at room temperature before 40,000 cells of each cell line per well were seeded. Six repeats were included for each cell line in each experiment. After an incubation of $45 \mathrm{~min}$ at $37^{\circ} \mathrm{C}$, nonadherent cells were removed by two washes with balanced salt solution (BSS) buffer. Adhered cells were then determined following a fixation in $4 \%$ formaldehyde and staining with crystal violet.

In vitro migration and invasion assay. ThinCer ${ }^{\mathrm{TM}}$ 24-well plate inserts with $8 \mu \mathrm{m}$ pores (Greiner Bio-One International $\mathrm{GmbH}$, Kremsmünster, Austria) were used for the following migration and invasion assay. The upper chamber was filled with $100 \mu \mathrm{l}$ DMEM containing $10 \%$ FBS, and the lower chamber was filled with $800 \mu 1$ the same solution. 100,000 cells were seeded into each insert. After 24-h incubation, migrated cells were determined after a fixation in $4 \%$ formalin and staining with crystal violet.

Each transwell insert was pre-coated with $100 \mu \mathrm{g}$ Matrigel (BD Matrigel Basement Membrane Matrix, Cat Number 354234; BD Bio-Science, Oxford, UK) before 20,000 cells for EJ138 or 40,000 cells for RT112 were seeded. After a culture of 48 hours, invaded cells were determined after fixation and staining.

Statistical analysis. SPSS 17.0 software (SPSS Inc., Chicago, IL, USA) was employed for statistical analyses. Non-normally distributed data were analysed using Mann-Whitney $U$-test, and normally distributed data using a two-sample $t$-test. Differences were considered significant at $p<0.05$.

\section{Results}

HOXB2 expression in bladder cancer from TCGA dataset. We analyzed $H O X B 2$ mRNA expression data of bladder cancer from the Cancer Genome Atlas (TCGA) dataset. UALCAN Dataset (18) indicated that $H O X B 2$ mRNA was significantly upregulated in papillary tumour subtype, compared with non-papillary tumor and normal tissues ( $p=0.0037$ and 0.0042 , Figure 1) (19). According to molecular subtypes, $H O X B 2$ mRNA was significantly upregulated in both luminal infiltrated and luminal papillary 

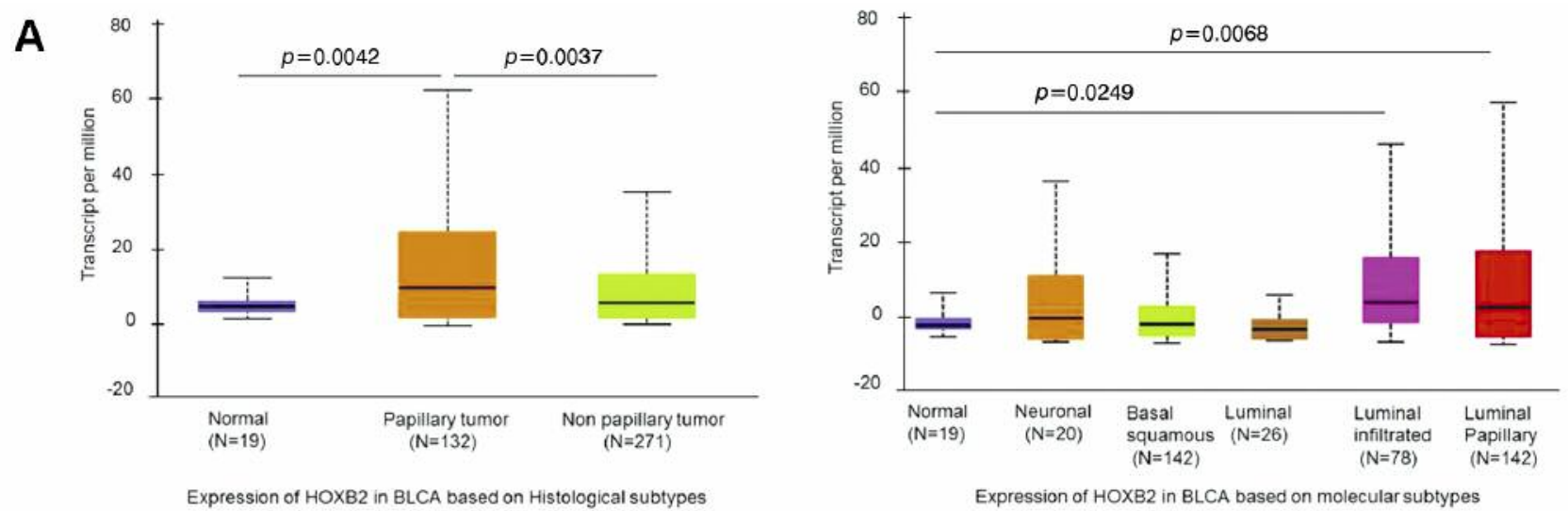

B

\begin{tabular}{lccc}
\hline NAME & NES & NOM p-val & FDR q-val \\
\hline KEGG_DRUG_METABOLIISM_CYTOCHROME_P450 & 1.8060501 & 0.000 & 0.0145755 \\
KEGG_STARCH_AND_SUCROSE_METABOLISM & 1.5529561 & 0.017 & 0.070551 \\
KEGG_METABOLISM_OF_XENOBIOTICS_BY_CYTOCHROME_P450 & 2.0584838 & 0.000 & 0.0012559 \\
KEGG_PORPHYRIN_AND_CHLOROPHYLL_METABOLISM & 1.3629242 & 0.093 & 0.1890384 \\
KEGG_FRUCTOSE_AND_MANNOSE_METABOLISM & 1.3534087 & 0.087 & $\mathbf{0 . 1 9 1 7 6 0 5}$ \\
\hline
\end{tabular}

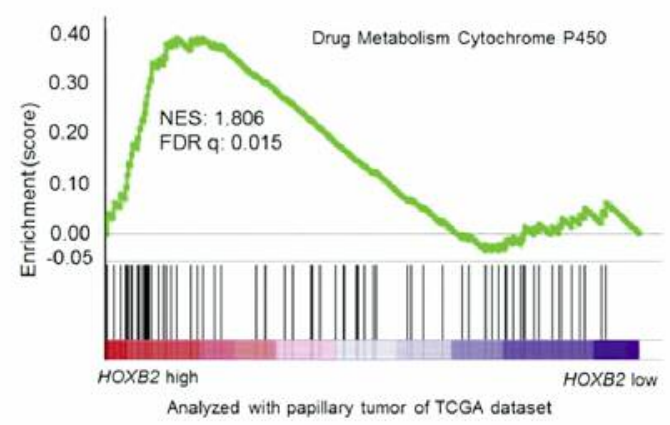

C

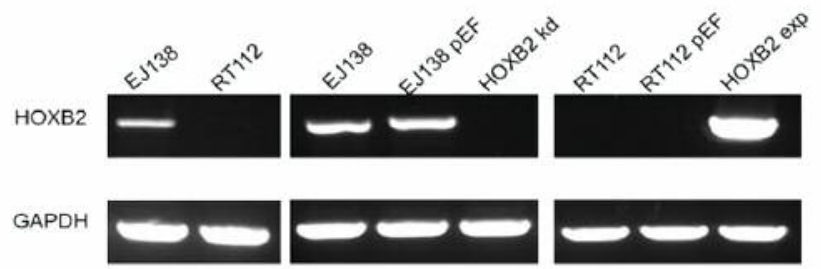

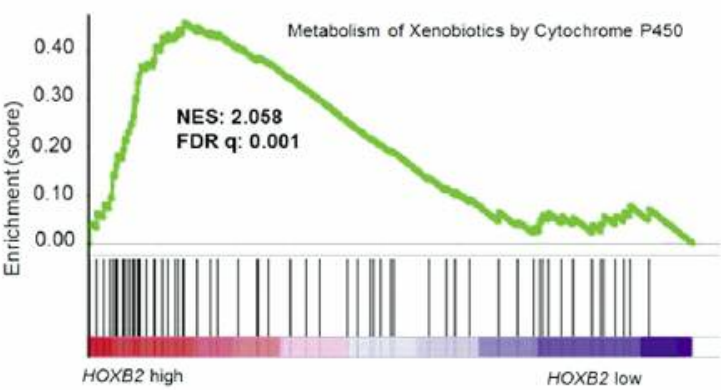

Analyzed with papilary tumor of TCGA dataset

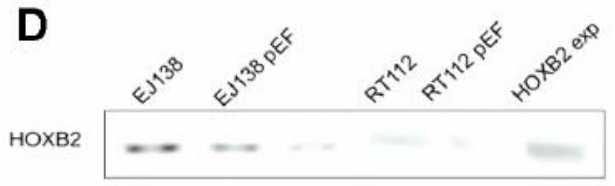

GAPDH

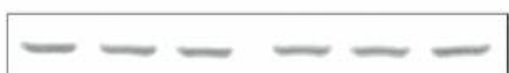

Figure 1. HOXB2 expression in BC. A) Differential expression of HOXB2 in different histological subtypes and molecular subtypes. B) Analysis of results from TCGA database showed that HOXB2 expression is associated with the activation of P450 pathway. C) The mRNA expression (PCR) of HOXB2 in EJ138 and RT112 cell lines before and after transfection. D) HOXB2 protein in the BC cell lines was examined using western blot analysis. GAPDH was included as a control.

subtypes, compared with normal tissues, $(p=0.0249$ and 0.0068 , Figure 1A) (19).

Relationship between HOXB2 gene expression and cytochrome $P 450$ pathway. To investigate the relationship between HOXB2 gene and some common pathogenic pathways, data from RNAseq results of the papillary subtype of bladder cancer in TCGA database (20) was used. This was followed by analyses using the Gene Set Enrichment
Analysis (GSEA) v3.0 (21). The high and low groups of TCGA papillary subtype of bladder cancer specimens were separated by the median value of HOXB2 mRNA expression levels (22). The hallmark of Kyoto Encyclopedia of Genes and Genomes (KEGG) gene sets indicated that the signaling pathways were enriched mainly on biochemical metabolic pathways; especially the Cytochrome P450 pathway was significantly enriched in the BCs with high HOXB2 expression (Figure 1B). 

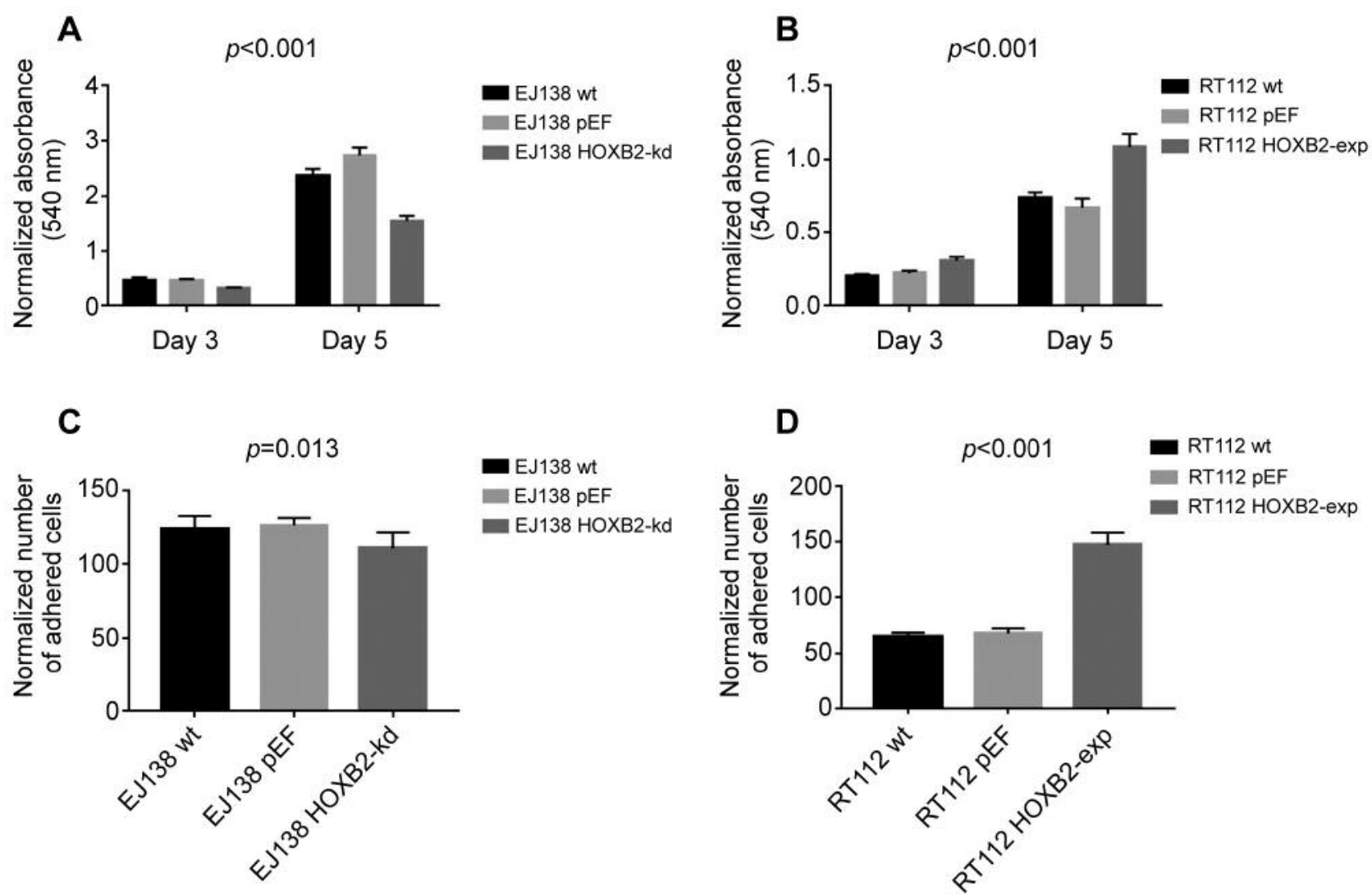

Figure 2. HOXB2 regulates growth and adhesion of BC cells. A) Growth of EJ138 HOXB2-kd cells was reduced compared to the controls. B) Growth of RT112 cells overexpressing HOXB2 (HOXB2-exp) over 3 days and 5 days culture was determined. C) Cell adhesion in EJ138 HOXB2-kd was remarkably reduced $(p=0.013)$. D) RT112 HOXB2-exp cells exhibited increased adhesion $(p<0.001)$.

Evaluation of HOXB2 levels in cell lines. HOXB2 transcripts in two different bladder cancer cell lines were detected using RT-PCR (Figure 1C). The expression of HOXB2 was high in EJ138 and low in RT112 cells. HOXB2 knockdown (HOXB2-kd) and overexpression (HOXB2-exp) were established in the EJ138 and RT112 cells, using anti-HOXB2 ribozyme and expressing constructed plasmids, respectively. After the selection using G418, HOXB2 expression in the transfected cells was determined using western blotting (Figure 1D). The HOXB2-modified EG138 and RT112 cell lines were used in the following experiments.

Effects of HOXB2 knockdown or overexpression on in vitro growth of bladder cancer cells. The effect of HOXB2 on in vitro cell growth was assessed using two cell models, namely EJ138 cells with HOXB2 knockdown and RT112 cells overexpressing HOXB2. EJ138 HOXB2-kd bladder cancer cells displayed a significantly reduced growth, $p<0.001$ compared with both control transfection and the wild type cells (Figure 2A). The RT112 HOXB2-exp cells, in which
HOXB2 expression had been up regulated, exhibited an increase of growth, $p<0.001$ compared with both control transfection and wild type RT112 cells (Figure 2B).

Impact on in vitro cell matrix adhesion of HOXB2 Knockdown or overexpression. Influence of $\mathrm{HOXB} 2$ on the adhesion of these bladder cancer cell lines was then evaluated. Down-regulation of HOXB2 in EJ138 remarkably reduced the adhesion in comparison with the controls, $p=0.013$ (Figure 2C), while the overexpression of HOXB2 resulted in an increase of adhesion in RT112 cells, $p<0.001$ (Figure 2D).

Effects of HOXB2 on in vitro invasion of bladder cancer cells. We performed a transwell assay to examine the impact of HOXB2 on invasiveness of the bladder cancer cell lines. Down-regulation of HOXB2 in EJ138 resulted in a marked reduction in invasion, $p<0.001$ (Figure $3 \mathrm{~A}$ ). But HOXB2 overexpression in RT112 cells had no effect on invasion compared with the control cells (Figure 3B). 
A

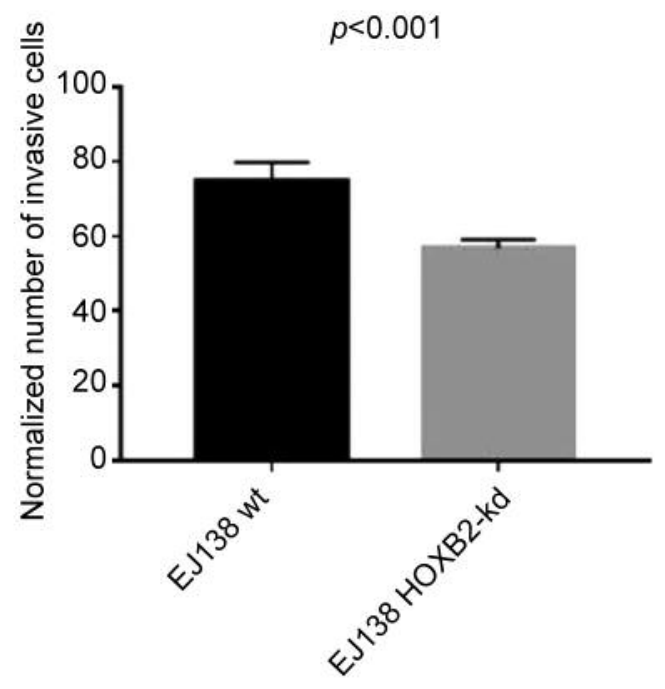

C

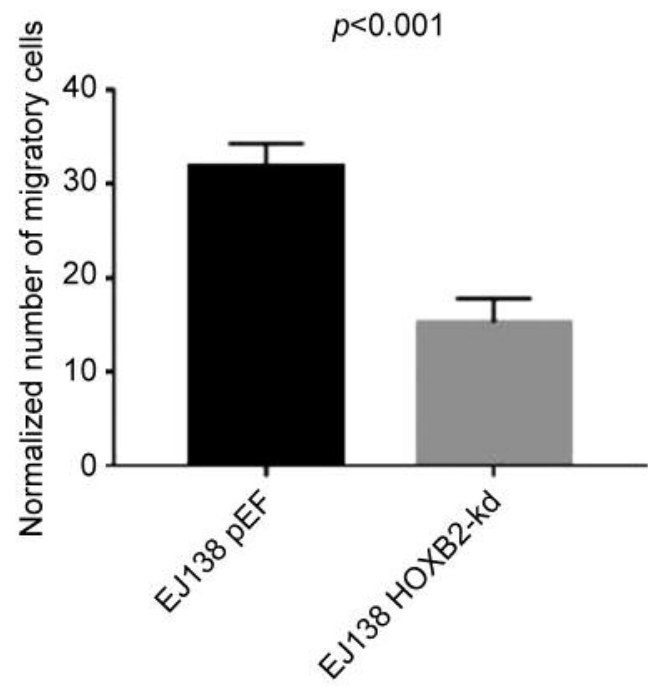

B

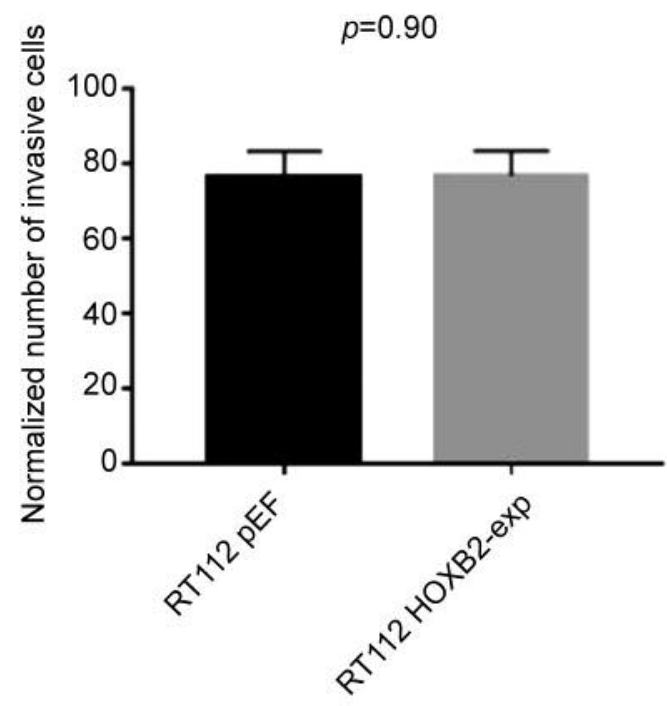

D

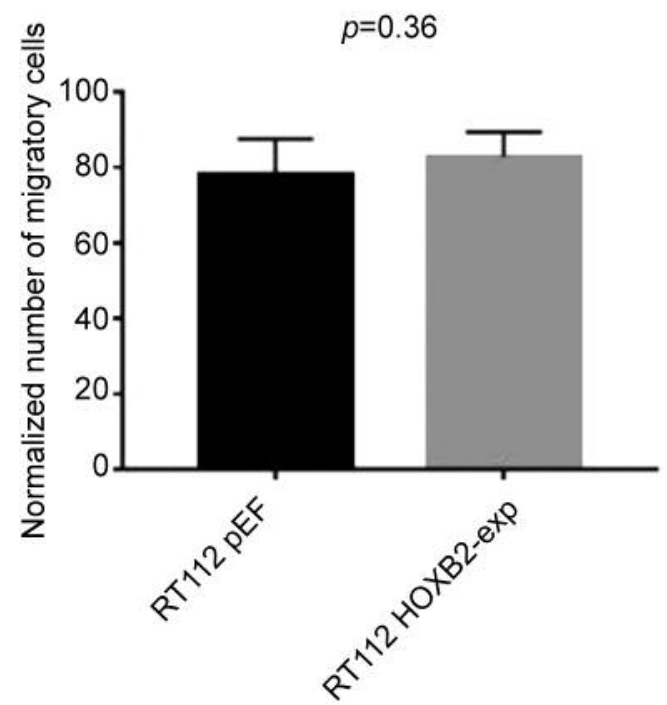

Figure 3. Effect of altered HOXB2 expression on invasion and migration of BC cells. A and C) Reduced invasiveness and migration were seen in the EJ138 HOXB2-kd cells. B and D) Invasion and migration of RT112 cells overexpressing HOXB2 (HOXB2-exp) cells were not different from the control cells.

Effects of HOXB2 on in vitro migration of bladder cancer cells. In vitro transwell chamber-based assay was also used to determine the migration and invasion of the $\mathrm{BC}$ cell lines following changes in HOXB2 expression. The number of HOXB2-kd EJ138 cells that migrated though the diaphragm membrane was lower than that of control cells, $p<0.001$ (Figure $3 \mathrm{C})$. In contrast, HOXB2 overexpression did not have a significant effect on the migration of RT112 cells (Figure 3D).

\section{Discussion}

Oncogenesis comprises numerous steps that lead to accumulation of genetic mutations and eventually an invasive phenotype. Aberrant epigenetic events are also critical for the tumourigenic process and subsequent evolution of neoplasia. This knowledge provides possibilities for developing novel therapeutic approaches (23). 
HOXB2 is involved in embryonic development of the external genitalia and urogenital tract (17). Differential expression of HOXB2 has been observed in certain solid tumours. For example, overexpression of HOXB2 has been evident in cervical cancer (24), lung adenocarcinomas (25) and pancreatic cancer (26), and has been correlated with disease progression. Elevated amplification of the HOXB2 gene has also been observed in cancerous samples (11/15) compared with healthy urothelium (4/15) (12). By analysing the data of the GEO database, we found that HOXB2 expression was increased in certain types of $\mathrm{BC}$ compared with the normal epithelium. Interestingly, this is only reflected in papillary urothelial cancer histological subtypes but not in non-papillary tumors, and has also been verified in molecular subtypes. It is well known that papillary urothelial carcinoma often shows non-invasive growth, and also predicts a better prognosis, while non-papillary urothelial carcinoma tends to show invasive growth and poor prognosis. These findings suggest that HOX is likely associated with the development of urothelial cancer of a specific type or period.

The Drug Metabolism Cytochrome P450 pathway, as part of Phase I metabolism in the detoxification of xenobiotics, has a possible involvement in tumourigenesis, disease progression and treatment of BC (27). In the present study, we used TCGA data retrieval and GSEA analysis to confirm the potential link between the HOXB2 gene and the P450 pathway, which requires further study.

Knockdown of HOXB2 in EJ138 cell lines and overexpression in RT112, resulted in opposite effects in the respective bladder cancer cells on proliferation, adhesion, invasion, and migration. These results suggested that HOXB2 plays a role in coordinating aggressive traits of $\mathrm{BC}$ cells. This was consistent with the results regarding other malignancies indicating that $\mathrm{HOXB} 2$ is a putative tumour activator in $\mathrm{BC}(28)$.

However, other studies have obtained different results. For example, knockdown of HOXB2 promoted growth of breast cancer cells (16). Additionally, HOXB2 presented an inhibitory effect in FLT3-ITD driven acute myeloid leukemia (29). These results indicate that the effects of $H O X B 2$ gene may be tissue or tumour specific.

Intermediate filament proteins, cytokeratins (CKs) are involved in cell-cell communication and in the maintenance of cell shape. Deregulated CK8, CK18 CK19 and CK20 have been observed in BCs (30-32). CK genes are located closely to the 3' end of the HOX locus (17). Thus, the involvement of both HOX and keratin genes in the tumorigenic process and the consequent evolution to an invasive phenotype warrants further investigation.

Taken together, our present study revealed an increased expression of HOXB2 in papillary BC. HOB2 promoted cell growth and adhesion of BC cells. Drug Metabolism Cytochrome $\mathrm{P} 450$ pathway was enriched in the BCs when HOXB2 was highly expressed.

\section{Conflicts of Interest}

The Authors declare no conflicts of interest regarding this study.

\section{Authors' Contributions}

JL, LS and XC carried out experimental work and data analyses, YY and WGJ conceived the study, PD and YY provided clinical samples. All Authors contributed to the preparation of the manuscript.

\section{References}

1 Chavan S, Bray F, Lortet-Tieulent J, Goodman M and Jemal A: International variations in bladder cancer incidence and mortality. Eur Urol 66(1): 59-73, 2014. PMID: 24451595. DOI: 10.1016/j.eururo.2013.10.001

2 Cheng L, Weaver AL, Leibovich BC, Ramnani DM, Neumann RM, Scherer BG, Nehra A, Zincke $H$ and Bostwick DG: Predicting the survival of bladder carcinoma patients treated with radical cystectomy. Cancer 88(10): 2326-2332, 2000. PMID: 10820355. DOI: 10.1002/(sici)1097-0142(20000515)88:10<2326: :aid-cncr17>3.0.co;2-t

3 Zhang $\mathrm{X}$ and Zhang Y: Bladder cancer and genetic mutations. Cell Biochem Biophys 73(1): 65-69, 2015. PMID: 27352265. DOI: $10.1007 / \mathrm{s} 12013-015-0574-\mathrm{z}$

4 Gehring WJ and Hiromi Y: Homeotic genes and the homeobox. Annu Rev Genet 20: 147-173, 1986. PMID: 2880555. DOI: 10.1146/annurev.ge.20.120186.001051

5 Seifert A, Werheid DF, Knapp SM and Tobiasch E: Role of hox genes in stem cell differentiation. World J Stem Cells 7(3): 583595, 2015. PMID: 4404393. DOI: 10.4252/wjsc.v7.i3.583

6 Lee JY, Kim JM, Jeong DS and Kim MH: Transcriptional activation of egfr by hoxb5 and its role in breast cancer cell invasion. Biochem Biophys Res Commun 503(4): 2924-2930, 2018. PMID: 30115380. DOI: 10.1016/j.bbrc.2018.08.071

7 Luo H, Wang F, Zha J, Li H, Yan B, Du Q, Yang F, Sobh A, Vulpe C, Drusbosky L, Cogle C, Chepelev I, Xu B, Nimer SD, Licht J, Qiu Y, Chen B, Xu M and Huang S: Ctcf boundary remodels chromatin domain and drives aberrant hox gene transcription in acute myeloid leukemia. Blood 132(8): 837-848, 2018. PMID: 6107877. DOI: 10.1182/blood-2017-11-814319

8 Wu Y, Zhou T, Tang Q and Xiao J: Hoxa5 inhibits tumor growth of gastric cancer under the regulation of microrna-196a. Gene 681: 62-68, 2018. PMID: 30267809. DOI: 10.1016/j.gene.2018. 09.051

9 Tang X, Jiang J, Zhu J, He N and Tan J: Hoxa4-regulated mir138 suppresses proliferation and gefitinib resistance in non-small cell lung cancer. Mol Genet Genomics, 2018. PMID: 30196354. DOI: $10.1007 / \mathrm{s} 00438-018-1489-3$

10 Huan HB, Yang DP, Wen XD, Chen XJ, Zhang L, Wu LL, Bie $\mathrm{P}$ and Xia F: Hoxb7 accelerates the malignant progression of hepatocellular carcinoma by promoting stemness and epithelialmesenchymal transition. J Exp Clin Cancer Res 36(1): 86, 2017. PMID: 5483250. DOI: 10.1186/s13046-017-0559-4

11 Kristiansen I, Stephan C, Jung K, Dietel M, Rieger A, Tolkach $\mathrm{Y}$ and Kristiansen G: Sensitivity of hoxb13 as a diagnostic immunohistochemical marker of prostatic origin in prostate cancer metastases: Comparison to psa, prostein, androgen receptor, erg, nkx3.1, psap, and psma. Int J Mol Sci 18(6), 2017. PMID: 5485975. DOI: 10.3390/ijms18061151 
12 Cantile M, Cindolo L, Napodano G, Altieri V and Cillo C: Hyperexpression of locus $\mathrm{c}$ genes in the hox network is strongly associated in vivo with human bladder transitional cell carcinomas. Oncogene 22(41): 6462-6468, 2003. PMID: 14508527. DOI: $10.1038 /$ sj.onc. 1206808

13 Adshead JM, Ogden CW, Penny MA, Stuart ET and Kessling AM: The expression of pax5 in human transitional cell carcinoma of the bladder: Relationship with de-differentiation. BJU Int 83(9): 1039-1044, 1999. PMID: 10368252. DOI: 10.1046/j.1464-410x.1999.00052.x

14 Guo B, Che T, Shi B, Guo L, Yin Y, Li L, Wang J, Yan D and Chen Y: Screening and identification of specific markers for bladder transitional cell carcinoma from urine urothelial cells with suppressive subtractive hybridization and cdna microarray Can Urol Assoc J 5(6): E129-137, 2011. PMID: 3235217. DOI: 10.5489/cuaj.09118

15 Acampora D, D’Esposito M, Faiella A, Pannese M, Migliaccio E, Morelli F, Stornaiuolo A, Nigro V, Simeone A and Boncinelli E: The human hox gene family. Nucleic Acids Res 17(24): 10385-10402, 1989. PMID: 335308.

16 Boimel PJ, Cruz C and Segall JE: A functional in vivo screen for regulators of tumor progression identifies hoxb2 as a regulator of tumor growth in breast cancer. Genomics 98(3): 164-172, 2011. PMID: 3165059. DOI: 10.1016/j.ygeno.2011.05.011

17 Cantile M, Franco R, Schiavo G, Procino A, Cindolo L, Botti G and Cillo $\mathrm{C}$ : The hox genes network in uro-genital cancers: Mechanisms and potential therapeutic implications. Curr Med Chem 18(32): 4872-4884, 2011. PMID: 22050740. DOI: 10.2174/092986711797535182

18 UALCAN portal database. Available at: http://ualcan.path.uab. edu/

19 Chandrashekar DS, Bashel B, Balasubramanya SAH, Creighton CJ, Ponce-Rodriguez I, Chakravarthi B and Varambally S: Ualcan: A portal for facilitating tumor subgroup gene expression and survival analyses. Neoplasia 19(8): 649-658, 2017. PMID: 28732212. DOI: $10.1016 /$ j.neo.2017.05.002

20 Broad Institute. Available at: http://gdac.broadinstitute.org (Last accessed 31/10/2019)

21 Gene Set Enrichment Analysis (GSEA). Available at: http://www.broadinstitute.org/gsea (Last accessed 31/10/2019)

22 Subramanian A, Tamayo P, Mootha VK, Mukherjee S, Ebert BL, Gillette MA, Paulovich A, Pomeroy SL, Golub TR, Lander ES and Mesirov JP: Gene set enrichment analysis: A knowledgebased approach for interpreting genome-wide expression profiles. Proc Natl Acad Sci USA 102(43): 15545-15550, 2005. PMID: 1239896. DOI: 10.1073/pnas.0506580102

23 Bantignies F and Cavalli G: Cellular memory and dynamic regulation of polycomb group proteins. Curr Opin Cell Biol 18(3): 275-283, 2006. PMID: 16650749. DOI: 10.1016/j.ceb.2006.04.003

24 Lopez R, Garrido E, Pina P, Hidalgo A, Lazos M, Ochoa R and Salcedo M: Hoxb homeobox gene expression in cervical carcinoma. Int J Gynecol Cancer 16(1): 329-335, 2006. PMID: 16445654. DOI: $10.1111 /$ j.1525-1438.2006.00350.x
25 Inamura K, Togashi Y, Okui M, Ninomiya H, Hiramatsu M, Satoh Y, Okumura S, Nakagawa K, Shimoji T, Noda T and Ishikawa Y: Hoxb2 as a novel prognostic indicator for stage $\mathrm{i}$ lung adenocarcinomas. J Thorac Oncol 2(9): 802-807, 2007. PMID: 17805056. DOI: 10.1097/JTO.0b013e3181461987

26 Segara D, Biankin AV, Kench JG, Langusch CC, Dawson AC, Skalicky DA, Gotley DC, Coleman MJ, Sutherland RL and Henshall SM: Expression of hoxb2, a retinoic acid signaling target in pancreatic cancer and pancreatic intraepithelial neoplasia. Clin Cancer Res 11(9): 3587-3596, 2005. PMID: 15867264. DOI: 10.1158/1078-0432.CCR-04-1813

27 Deng XD, Gao Q, Zhang B, Zhang LX, Zhang W, Mu Er ZE, Xie Y, Ma Y and Liu Y: Functional rsai/psti polymorphism in cytochrome p450 2e1 contributes to bladder cancer susceptibility: Evidence from a meta-analysis. Asian Pac J Cancer Prev 15(12): 4977-4982, 2014. PMID: 24998574. DOI: 10.7314/apjcp. 2014.15.12.4977

28 Marsit CJ, Houseman EA, Christensen BC, Gagne L, Wrensch MR, Nelson HH, Wiemels J, Zheng S, Wiencke JK, Andrew AS, Schned AR, Karagas MR, Kelsey KT: Identification of methylated genes associated with aggressive bladder cancer. PLoS One 5(8): e12334, 2010. PMID: 20808801. DOI: 10.1371/journal.pone.0012334

29 Lindblad O, Chougule RA, Moharram SA, Kabir NN, Sun J, Kazi JU and Ronnstrand L: The role of hoxb2 and hoxb3 in acute myeloid leukemia. Biochem Biophys Res Commun 467(4): 742747, 2015. PMID: 26482852. DOI: 10.1016/j.bbrc.2015.10.071

30 Stieber P, Schmeller N, Schambeck C, Hofmann K, Reiter W, Hasholzner U and Fateh-Moghadam A: Clinical relevance of CYFRA 21-1, TPA-IRMA and TPA-LIA-mat in urinary bladder cancer. Anticancer Res 16(6B): 3793-3798, 1996. PMID: 9042259.

31 Ribal MJ, Mengual L, Marín M, Algaba F, Ars E, Fernández PL, Oliva R, Villavicencio H and Alcaraz A: Molecular staging of bladder cancer with RTPCR assay for CK20 in peripheral blood, bonemarrow and lymph nodes: comparison with standard histological staging. Anticancer Res 26(1A): 411-419, 2006. PMID: 16475726.

32 Moll R, Franke WW, Schiller DL, Geiger B and Krepler R: The catalog of human cytokeratins: Patterns of expression in normal epithelia, tumors and cultured cells. Cell 31(1): 11-24, 1982. PMID: 6186379. DOI: 10.1016/0092-8674(82)90400-7
Received October 1, 2019

Revised October 30, 2019 Accepted October 31, 2019 